\title{
Membangun Kerukunan Antar Umat Beragama : Belajar dari Desa Balun, Kabupaten Lamongan
}

\author{
Galang Setia Abadi \\ Pegawai Kecamatan Kedung Adem, Kab. Bojonegoro \\ gsabadi@gmail.com \\ Asrofatul Azizah \\ Pendamping Program Keluarga Harapan, Kabupaten Lamongan \\ asroazizah@gmail.com
}

Received: 01 Juli 2020; Revised: 10 Juli 2020; Accepted : 20 Juli 2020; Published : Agustus 2020; Available online : Agustus 2020.

\begin{abstract}
Indonesian society has local cultures and traditions that are functionally able to maintain the environment situation in order to remain harmonious, both with fellow humans and the environment. These local traditions have important meanings and values, among others, as a reference for the behavior of the people in living their lives, including dealing with differences in interacting with other people with different cultures. These local traditions are actually the expression of local knowledge or local wisdom of a community in responding to their environmental situation. Balun Community Balun Village Balun District Lamongan Regency is able to maintain religious harmony, even though they have different religions. This is due to the existence of elements which become social glue in the form of local wisdoms that live in Balun society. Substantially, local wisdom is the values that apply in a society. These values are believed to be true and become a reference in the daily behavior of the local community. These local wisdom values are seen as entities that determine dignity and human dignity in the community because it contains elements of creative intelligence and local knowledge from the elite and the community. Research conducted with this qualitative approach reveals local wisdom in the Balun community in maintaining harmony in the form of traditional expressions and festivity. The Balun community has a harmonious social outlook expressed through various traditional expressions such as the pillars of agawe santosa crah agawe bubrah.
\end{abstract}

Keywords: Local Wisdom, Tolerance, Balun 


\section{Pendahuluan}

Kearifan lokal adalah nilai-nilai yang berlaku dalam suatu masyarakat. Nilai-nilai tersebut diyakini kebenarannya dan menjadi acuan dalam bertingkah laku sehari-hari masyarakat setempat. Nilai-nilai kearifan lokal ini dipandang sebagai entitas yang sangat menentukan harkat dan martabat manusia dalam komunitasnya karena di dalamnya berisi unsur kecerdasan kreativitas dan pengetahuan lokal dari para elit dan masyarakatnya. Nilai-nilai kearifan lokal dalam bentuk tradisi maupun norma-norma sosial di masyarakat secara fungsional dapat memperkuat sistem budaya sebagai acuan dalam kehidupan masyarakat, yang kemudian dipercayai dan diakui sebagai elemen penting sehingga mampu mempertebal kohesi sosial diantara warga masyarakat. ${ }^{1}$ Dengan demikian kearifan lokal dapat menjadi elemen perekat (kohesi) sosial dalam kehidupan lintas agama, lintas kepercayaan, dan bahkan lintas budaya, sehingga dapat memberi warna kebersamaan secara dinamis dan damai, terutama dalam masyarakat yang multikultur.

\footnotetext{
1 John Haba, Revitalisasi Kearifan Lokal: Studi Resolusi Konflik di Kalimantan Barat, Maluku, dan Poso, (Jakarta: ICIP dan Eropean Commision, 2007), h. 11.
}

Masyarakat Jawa telah dikenal sebagai orang yang sangat menjunjung tinggi nilai-nilai kerukunan dan keharmonisan dalam masyarakat. Dalam penelitian tentang keluarga Jawa, Hildred Geertz $^{2}$ mengungkapkan dua kaidah penting yang mengatur sikap perilaku masyarakat Jawa hubungan sosial. Kaidah atau nilai kejawaan yang penting tentang kehidupan orang Jawa yang merupakan petunjuk moral yang mendasari tindak-tanduk atau perilaku dalam lingkungannya adalah pandangan tentang tata krama penghormatan, dan penampilan sosial yang harmonis.

Dua kaidah tersebut disimpulkan oleh Franz Magnis Suseno ${ }^{3}$, dalam kajiannya tentang Etika Jawa, sebagai prinsip hormat dan prinsip rukun. Prinsip rukun menuntut agar manusia dalam berbicara dan membawa diri harus selalu menunjukkan sikap hormat kepada orang lain sesuai derajat dan kedudukannya. Sedangkan prinsip kedua menuntut agar dalam setiap situasi manusia hendaknya bersikap sedemikian rupa sehingga tidak sampai menimbulkan konflik. Dengan demikian, setiap orang dalam masyarakat Jawa

\footnotetext{
2 Hildred Geertz, Keluarga Jawa, (Jakarta: Grafiti Press, 1985), h. 151.

3 Franz Magnis Suseno, Etika Jawa, Sebuah Analisa Falsafi tentang Kebijaksanaan Hidup Jawa, (Jakarta: PT. Gramedia Pustaka Utama, 2003), h. 38.
} 
diharapkan berperilaku sesuai dengan dua prinsip tersebut. Hal ini menjadikan dalam masyarakat yang berlatar belakang Jawa mampu memelihara kerukunan.

Kearifan lokal sebagai bentuk kecerdasan lokal masyarakat mengatasi persoalan hidupnya, terutama yang berkaitan dengan hubungan atau interaksi sosial. Terlebih dalam masyarakat yang heterogen dan plural, terutama perbedaan agama, memiliki potensi terjadi konflik antarumat beragama. Tantangan semacam ini, tentunya mendorong masyarakat itu sendiri untuk memelihara nilai-nilai tradisi lokal yang mampu menyelesaikan atau meredam munculnya konflik tersebut. Di antara wilayah yang selama ini telah dikenal sebagai masyarakat yang plural tetapi mampu mempertahankan kerukunan adalah masyarakat Balun, yakni di desa Balun Kecamatan Balun Kabupaten Lamongan. Dimana meskipun mayoritas masyarakatnya memeluk agama Islam, tetapi di desa ini terdapat umat Kristen dan bahkan juga Hindu. Umat Islam, Kristen dan Hindu di wilayah Balun ini berinteraksi dengan baik dan tercipta kerukunan beragama. Tulisan ini bertujuan mendeskripsikan dinamika kerukunan dalam masyarakat Balun
Desa Balun, Kecamatan Balun Kabupaten Lamongan, dan mengungkapkan ungkapan-ungkapan tradisional yang mendukung terpeliharanya kerukunan tersebut.

Dari uraian di atas dapat di tarik permasalahan sebagai berikut: Bagaimana ajaran kearifan lokal di Balun bisa menciptakan toleransi antar umat beragama. Bagaimana masyarakat di Balun melestarikan dan mensosialisasikan ajaran kearifan lokal tersebut.

\section{PEMBAHASAN}

\section{Kearifan Lokal}

E. Tiezzi, N. Marchettini, \& M. Rossini menjelaskan kearifan lokal sebagai pengetahuan yang eksplisit yang muncul dari periode panjang yang berevolusi bersama-sama masyarakat dan lingkungannya dalam sistem lokal yang sudah dialami bersama-sama. Secara substansial, kearifan lokal itu adalah nilai-nilai yang berlaku dalam suatu masyarakat. Nilai-nilai yang diyakini kebenarannya dan menjadi acuan dalam bertingkah-laku sehari-hari masyarakat setempat. Kearifan yang tersebut diungkapkan dalam bentuk kata-kata bijak (falsafah) berupa nasehat, pepatah, pantun, syair, folklor (cerita lesan) dan sebagainya; aturan, prinsip, norma dan tata aturan sosial 
dan moral yang menjadi sistem sosial; ritus, seremonial atau upacara tradisi dan ritual; serta kebiasaan yang terlihat dalam perilaku sehari-hari dalam pergaulan sosial. ${ }^{4}$

Salah satu bentuk kearifan lokal tersebut adalah ungkapan-ungkapan tradisional. Ungkapan tradisional adalah kata atau kelompok kata yang memiliki makna kiasan, konotatif, simbolis yang berasal dari tradisi atau kebiasaan turun-temurun masyarakat lokal dan diyakini mempunyai fungsi. Ungkapan-ungkapan tersebut disarikan dari pengalaman panjang masyarakat yang dimunculkan dari kecerdasan lokal menjadi kebijaksanaan bersama masyarakat. Sebagai sebuah tradisi dan folklor lisan, maka ungkapan tradisional mempunyai nilai-nilai yang dijabarkan dari pandangan hidup masyarakat pembuatnya. Dengan mengambil nilainilai ungkapan tradisional, maka masyarakat bisa memahami bagaimana nenek moyang atau masyarakat yang menghasilkan ungkapan tersebut memandang dan menyikapi hidup. Agar tercipta keselarasan dan keharmonisan, oleh karena itu secara umum masyarakat Jawa dipandang sebagai masyarakat yang selalu berpijak pada terciptanya

${ }^{4}$ Rohimin, et.al, Harmonisasi Agama dan Budaya di Indonesia, (Jakarta: Balai Litbang Agama Jakarta, 2009), h. 207. harmoni manusia dengan Tuhan, sesamanya, masyarakat, dan lingkungan. ${ }^{5}$

Terkait dengan persoalan interaksi antarmanusia, terutama kerukunan hidup dalam masyarakat, menurut John Haba6, setidaknya ada enam signifikansi serta fungsi sebuah kearifan lokal jika hendak dimanfaatkan sebagai salah satu bentuk pendekatan dalam menyelesaikan sebuah konflik. Pertama, sebagai penanda identitas sebuah komunitas. Kedua, elemen perekat (aspek kohesif) lintas warga, lintas agama dan kepercayaan. Ketiga, kearifan lokal tidak bersifat memaksa atau dari atas (top down), tetapi sebuah unsur kultural yang ada dan hidup dalam masyarakat. Karena itu, daya ikatnya lebih mengena dan bertahan. Keempat, kearifan lokal memberikan warna kebersamaan bagi sebuah komunitas. Kelima, local wisdom akan merubah pola pikir dan hubungan timbal balik individu dan kelompok, dengan meletakkannya di

\footnotetext{
5 Sri Harti Widyastuti, "Reaktualisasi Ungkapan Tradisional Jawa sebagai Sumber Kearifan Lokal dalam Masyarakat untuk Penguat Kepribadian Bangsa", makalah, Konggres Bahasa Jawa ke-5 dikutip dalam http://ki-demang.com/kbj5 , diunduh 14 Oktober 2017.

${ }^{6}$ Dalam Alpha Amirrachman, Revitalisasi Kearifan Lokal: Studi Resolusi Konflik di Kalimantan Barat, Maluku dan Poso, (Jakarta: ICIP dan European Commission (EC), 2007), h. 334-335. Dapat diakses pada www.lsaf.org/content/view/176/150/, diunduh 17 Oktober 2017.
} 
atas common ground/kebudayaan yang dimiliki. Keenam, kearifan lokal dapat berfungsi mendorong terbangunnya kebersamaan, apresiasi sekaligus sebagai sebuah mekanisme bersama untuk menepis berbagai kemungkinan yang meredusir, bahkan merusak, solidaritas komunal, yang dipercayai berasal dan bertumbuh di atas kesadaran bersama, dari sebuah komunitas terintegrasi.

\section{Ungkapan Tradisional Masyarakat} Jawa

Budaya Jawa yang menekankan hidup rukun menjadikan masyarakat berupaya menjaga kerukunan tersebut. Nilai-nilai budaya Jawa, seperti sikap penghormatan, sikap rukun, toleransi, dan sebagainya menjadi acuan moral dan tingkah laku dalam berhubungan antarumat beragama. Pengalaman panjang orang Jawa dalam menjalani kehidupan bersama, berinteraksi dengan sesama manusia, pencapaian tujuan pribadinya maupun tujuan bersama menjadikan orang Jawa arif dalam menjalaninya. Nilai budaya ini diungkapkan dalam berbagai tradisi yang didalamnya mengandung kearifan lokal dalam menjalani hidup bersama. Tradisitradisi tersebut menjadi kristalisasi kecerdasan masyarakat Jawa menghadapi persoalan hidup yang muncul dalam hubungannya dengan sesama manusia.

Di antara tradisi masyarakat yang menyimpan kearifan lokal tersebut adalah tradisi lesan yang berupa ungkapan-ungkapan tradisional. Menurut Dananjaya ${ }^{7}$ ungkapan tradisional ini awalnya dinyatakan secara spontan, kemudian menjadi kebiasaan dan dapat dikatakan klise. Makna dalam ungkapan ini dapat bersifat instruktif, inperatif, ataupun preventif. Biasanya ungkapan-ungkapan tradisional bersifat anonim atau tidak diketahui siapa penciptanya. Ciri-ciri lainnya dari ungkapan tradisional ini adalah: 1. Merupakan alat pencerminan suatu angan-angan yang bersifat kolektif; 2 . Sebagai alat pengesahan pranata; 3 . Sebagai media pendidikan non-formal; 3 . Sebagai alat pemaksa dan pengawas, agar norma-norma masyarakat dapat dipenuhi.

Ungkapan tradisional adalah kata atau kelompok kata yang memiliki makna kiasan, konotatif, simbolis yang berasal dari tradisi atau kebiasaan turun-temurun masyarakat lokal dan diyakini mempunyai fungsi. Ungkapanungkapan tersebut disarikan dari pengalaman panjang masyarakat yang

\footnotetext{
7 Samidi Khalim, Tradisi Lisan Masyarakat Jawa, (Semarang: Prima Media Press, 2009), h. 33.
} 
dimunculkan dari kecerdasan lokal menjadi kebijaksanaan bersama masyarakat. Sebagai sebuah tradisi dan folklor lisan, maka ungkapan tradisional mempunyai nilai-nilai yang dijabarkan dari pandangan hidup masyarakat pembuatnya. Dengan mengambil nilainilai ungkapan tradisional, maka masyarakat bisa memahami bagaimana nenek moyang atau masyarakat yang menghasilkan ungkapan tersebut memandang dan menyikapi hidup. Agar tercipta keselarasan dan keharmonisan, oleh karena itu secara umum masyarakat Jawa dipandang sebagai masyarakat yang selalu berpijak pada terciptanya harmoni manusia dengan Tuhan, sesamanya, masyarakat, dan lingkungan. ${ }^{8}$

Dengan demikian, ungkapanungkapan tradisional dalam masyarakat memiliki peran sebagai acuan moral dalam menjalani kehidupan bersama secara rukun dan damai, sekaligus menjadi media transformasi nilai-nilai kerukunan tersebut pada masyarakat dan generasi selanjutnya. Masyarakat menjalani interaksi sosialnya dengan orang lain akan dinilai dari

\footnotetext{
8 Sri Harti Widyastuti, "Reaktualisasi Ungkapan Tradisional Jawa Sebagai Sumber Kearifan Lokal dalam Masyarakat untuk Penguat Kepribadian Bangsa", makalah, Konggres Bahasa Jawa ke-5 dikutip dalam http://ki-demang.com/kbj5 , diunduh 14 September 2017.
}

kesesuaiannya dengan nilai-nilai moralitas tersebut. Oleh karena itu, ungkapanungkapan tradisional dalam masyarakat Jawa tidak hanya berupa ungkapan yang bernada positif, tetapi juga menggunakan istilah negatif sebagai bentuk kritik terhadap perilaku yang negatif tersebut. Ungkapan-ungkapan tersebut, baik yang positif maupun negatif sama-sama memiliki fungsi sebagai acuan moral, tentang apa yang baik dan buruk dalam perilaku manusia dalam kehidupannya.

Ungkapan Jawa terinci dalam banyak jenis, diantaranya berupa: wangsalan, parikan, sanepa, tembung entar, paribasan, bebasan, dan saloka. Wangsalan itu adalah ungkapan yang ungkapan sejenis tebakan atau tekateki yang jawaban atau tebakannya berupa suku kata tersamar di dalam tubuh ungkapan itu sendiri. Parikan adalah ungkapan yang memiliki aturan persajakan, sampiran, isi, dan jumlah baris yang dibutuhkan. Sanepa adalah ungkapan yang berfungsi untuk menggambarkan situasi atau keadaan secara berlebih atau menyangatkan dengan cara pengandaian. Tembung entar adalah ungkapan yang maknanya kiasan, berbentuk perumpamaan, dan berfungsi untuk menyindir tingkah laku atau sifat seseorang. 
Paribasan adalah ungkapan yang digunakan secara ajeg/tidak boleh diganti, serta tidak berupa perumpamaan, fungsinya untuk menggambarkan keadaan, tingkah laku atau kehendak seseorang. Bebasan merupakan ungkapan yang berisi perumpamaan, diungkapkan secara ajeg, dan berfungsi untuk mengungkapkan keadan dan tingkah laku orang yang digambarkan.

$$
\text { Fokus perumpamaan terletak }
$$
pada tingkah laku dan keadaannya. Saloka adalah ungkapan yang menggambarkan perilaku dan keadaan seseorang dengan perumpamaan. Adapun yang dianalogikan/ diperumpamakan adalah orangnya. ${ }^{9}$

Selain jenis pengungkapan tersebut, masih terdapat jenis lainnya seperti pepali ora ilok dan kereta basa atau jarwa dhosok. Pepali ora ilok merupakan bentuk larangan melakukan sesuatu yang dipandang tidak baik atau berakibat tidak baik bagi pelakunya. Sedangkan kereta basa atau jarwa dhosok adalah mengandaikan makna dari nama sesuatu atau kata tertentu dengan menganggapnya sebagai akronim

9 Endang Nurhayati, "Nilai-Nilai Luhur dalam Ungkapan Jawa sebagai Fondamen Kehidupan Masyarakat Berbudaya", makalah, Konggres Bahasa Jawa ke-5 dikutip dalam

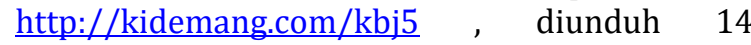
September 2017. dengan kepanjangannya sebagai makna yang dimaksud.

\section{Dinamika Kerukunan Masyarakat} Balun

Balun merupakan sebuah desa yang masih memegang erat nilai-nilai sejarahnya, kata Balun besar terhadap terbentuknya desa Balun sejak tahun 1600-an. ${ }^{10}$ Mbah Alun yang dikenal sebagai Sunan Tawang Alun I atau Mbah Sin Arih konon adalah Raja Blambangan bernama Bedande Sakte Bhreau Arih yang bergelar Raja Tawang Alun I yang lahir di Lumajang tahun 1574. Dia merupakan anak dari Minak Lumpat yang menurut buku Babat Sembar adalah keturunan Lembu Miruda dari Majapahit (Brawijaya). Mbah Alun belajar mengaji di bawah asuhan Sunan Giri IV (Sunan Prapen). Selesai mengaji beliau kembali ke tempat asalnya untuk menyiarkan agama Islam sebelum diangkat menjadi Raja Blambangan.

Selama pemerintahannya (tahun 1633-1639) Blambangan mendapatkan serangan dari Mataram dan Belanda hingga kedaton Blambangan hancur. Saat itu Sunan tawang Alun melarikan diri ke arah barat menuju Brondong untuk mencari perlindungan dari anaknya yaitu Ki Lanang Dhangiran (Sunan Brondong),

10 Sejarah Desa Balun, Balun, Balun, Lamongan, (www.wikipedia.org/wiki/Balun, Balun,

Lamongan.com), diakses pada tanggal 2 Mei 2018 
lalu diberi tempat di desa kuno bernama Candipari (kini menjadi desa Balun) untuk bersembunyi dari kejaran musuh Disinilah Sunan Tawang Alun I mulai mengajar mengaji dan menyiarkan ajaran Islam sampai wafat Tahun 1654 berusia 80 tahun sebagai seorang Waliyullah.

$$
\text { Sebab menyembunyikan }
$$

identitasnya sebagai Raja, maka beliau dikenal sebagai seorang ulama dengan sebutan Raden Alun atau Sin Arih. Sunan Tawang Alun I sebagai ulama hasil gemblengan Pesantren Giri. ${ }^{11}$ Kedaton ini menguasai ilmu Laduni, Fiqh, Tafsir, Syariat dan Tasawuf. Sehingga dalam dirinya dikenal tegas, kesatria, cerdas, Alim, Arif, persuatif, dan yang terkenal adalah sifat toleransinya terhadap orang lain, terhadap budaya lokal dan toleransinya terhadap agama lain.

Desa tempat makam Mbah Alun ini kemudian disebut Desa Mbah Alun dan kini Menjadi Desa Balun, Kecamatan Balun. Dan makamnya sampai sekarang masih banyak di ziarahi oleh orangorang dari daerah lain, apalagi bila hari Jum'at kliwon banyak sekali rombonganrombongan peziarah yang datang ke desa Balun. Pasca G 30S PKI tepatnya pertengahan tahun 1967 Kristen dan

11 Wawancara dengan Sumitro (tokoh agama Islam Desa Balun), pada tanggal 2 Juni 2018
Hindu mulai masuk dan berkembang di Desa Balun. ${ }^{12}$ Berawal dari adanya pembersihan pada orang-orang yang terlibat dengan PKI termasuk para pamong desa yang diduga terlibat. Akibatnya terjadi kekosongan kepala desa dan perangkatnya. Maka, untuk menjaga dan menjalankan pemerintahan desa ditunjuklah seorang prajurit untuk menjadi pejabat sementara di desa Balun. Prajurit tersebut bernama Pak Batih yang beragama Kristen. Dari sinilah Kristen mulai dapat pengikut, kemudian pak Batih mengambil teman dan pendeta untuk membabtis para pemeluk baru. Karena sikap keterbukaan dan toleransi yang tinggi dalam masyarakat Balun maka penetrasi Kristen tidak menimbulkan gejolak. Di samping itu kristen tidak melakukan dakwa dengan ancaman atau kekerasan. Pada tahun yang sama yakni akhir tahun 1967 juga masuk pembawa agama Hindu yang datang dari desa sebelah yaitu Plosowayuh.

Adapun tokoh sesepuh Hindu adalah bapak Tahardono Sasmito. ${ }^{13}$ Agama hindu inipun tidak membawa gejolak pada masyarakat umumnya.

\footnotetext{
12 Wawancara dengan Khusairi (Kepala Desa balun), pada tanggal 8 Juni 2018

13 Wawancara dengan Adi Wiyono (Tokoh Agama Hindu Desa Balun), pada tanggal 18 Mei 2018
} 
Masuknya seseorang pada agama baru lebih pada awalnya lebih disebabkan oleh ketertarikan pribadi tanpa ada paksaan. Sebagai agama pendatang di desa Balun, Kristen dan Hindu berkembang secara perlahan-lahan. Mulai melakukan sembahyang di rumah tokoh-tokoh agama mereka, kemudian pertambahan pemeluk baru dan dengan semangat swadaya yang tinggi mulai membangun tempat ibadah sederhana dan setelah melewati tahap-tahap perkembangan sampai akhirnya berdirilah Gereja dan Pura yang megah. Desa Balun adalah salah satu desa tua yang ada di kabupaten Lamongan yang masih memelihara budaya-budaya terdahulunya. Di samping itu keanekaragaman agama semakin memperkaya budaya desa Balun dan yang menjadi ciri khas adalah interaksi sosial di antara warganya yang plural tentu, agama (Islam, Kristen, Hindu). Sejak masuknya Hindu dan Kristen tahun 1967 dan Islam sebagai agama asli. Tahun 1967 sebagai saksi adanya penghormatan atas perbedaan agama. Adanya menjungjung tinggi tentang agama, adanya perbedaan itu bukan diingkari melainkan untuk dihargai. Peristiwa itu mampu menghipnotis dan memberikan ajaran tentang toleransi kepada masyarakat tentang arti persatuan yang utuh. Rasa naisonal yang tinggi membuat masyarakat lebih mengedepankan rasa toleransi.

Masyarakat Balun dapat dilihat dalam kerangka sosiologi pedesaan sebagai gambaran prototype masyarakat pedesaan Jawa. Masyarakat pedesaan yang ramah terhadap semua orang, di mana apabila mereka saling bertemu mereka saling menyapa, bahkan terhadap orang yang tidak dikenal pun apabila berpapasan di jalan akan saling menegur, meski hanya dengan mengucapkan "mangga". Hal ini karena bagi masyarakat, hidup itu harus srawung, istilah untuk menunjukkan sikap mau mengenal dan bersama dengan orang lain.

Masyarakat Balun merupakan masyarakat yang plural. Di desa Balun, khususnya di lingkungan Balun terdapat umat Islam, umat Katolik, dan umat Kristen yang hidup secara membaur dan dampingan secara damai dan rukun. Interaksi sosial yang terjalin di dalamnya berjalan dengan baik, terutama karena didukung dengan budaya Jawa yang melingkupi masyarakat Balun. Kerukunan di Desa Balun ini terjalin dalam dinamika atau proses sosial, yang meliputi interaksi assosiatif maupun dissosiatif, sehingga situasi perdamaian yang ditunjukkan oleh masyarakat Balun, 
termasuk hubungan antarumat beragama, umat Islam dan umat Katolik dalam berbagai aktivitas kemasyarakat.

Dinamika dalam sifat assosiatif dapat dilihat dalam aktivitas bersama warga masyarakat Balun yang guyub rukun. Guyub artinya kebersamaan, di mana berbagai kegiatan kemasyarakatan dilaksanakan secara bersamasama. Hal ini dilakukan oleh masyarakat Balun tanpa memandang agama. Kegiatan yang merupakan kepentingan bersama, akan dilaksanakan bersama oleh warga dan partisipasi seluruh warga tanpa memandang berbedaan agama.

\section{Ungkapan Tradisional dalam}

\section{Memelihara Kerukunan}

Satu faktor yang mendukung terwujudnya kerukunan umat beragama di Balun adalah budaya Jawa. Masyarakat Balun sebagai etnis Jawa menganut sistem nilai Jawa yang sangat menjunjung tinggi prinsip hormat dan rukun. Budaya Jawa dalam perikehidupan masyarakat menjadi acuan moral dan tingkah laku banyak terdapat dalam ungkapan-ungkapan yang sering muncul dalam pembicaraan ada saat terjadi suatu peristiwa tertentu, tidak terkecuali dalam konteks hubungan antar manusia dan antar umat beragama. Ungkapan tradisioanl tersebut mengandung kearifan lokal yang mampu mendorong masyarakatnya pada kerukunan hidup. Persoalan dalam interaksi sosial, bagaimana menjaga keharmonisan dan mencegah konflik, dikerangkai dengan norma kerukunan yang secara eksplisit disampaikan melalui ungkapan tradisional.

Salah satu ungkapan yang langsung berkaitan dengan tema kerukunan adalah paribasan rukun agawe santosa crah agawe bubrah. Secara semantik, kata rukun menunjukkan kondisi damai dan bermakna pula sikap guyub, sehingga muncul pula istilah guyub rukun. Kata guyub rukun merupakan tautologi, atau pengulangan yang memiliki arti yang sama atau hampir sama sehingga bermakna melebihkan atau menekankan arti tersebut. Kata guyub sendiri berarti rukun, kebersamaan, bersama-sama, sedangkan rukun adalah kondisi damai tanpa konflik. Dengan demikian guyub rukun adalah kondisi rukun tanpa konflik dalam kehidupan bersama dan berusaha dalam kebersamaan. Sementara santosa berarti kuat atau kokoh. Dalam konteks sosial, rukun agawe santosa berarti bahwa kondisi yang rukun dan damai akan memberi kesempatan pada masyarakat untuk menguatkan diri, 
misalnya kuat secara ekonomi yang berarti meningkatnya kesejahteraan. Sebaliknya crah agawe bubrah artinya konflik akan membuahkan kerusakan. Crah artinya perpecahan, pertikaian, dan konflik; sedangkan bubrah artinya bubar, rusak, bercerai berai.

Kondisi yang diwarnaai perpecahan atau konflik tidak saja menjadikan situasi tidak rukun, tetapi juga menyebabkan kerusakan. Dengan demikian, melalui paribasan ini, masyarakat mengkerangkai hidup bersama orang lain dalam suatu lingkungan masyarakat harus bersikap rukun dan berusaha menjaga kerukunan sehingga dapat menguatkan masyarakat, dan sebaliknya menjaga sikap dan lingkungannya agar tidak crah atau berkonflik dengan orang lain karena akan mengakibatan sesuatu yang buruk bagi diri maupun masyarakat. Norma rukun ini dalam prakteknya menuntut anggota masyarakat untuk menjaga hubungan baik dengan orang lain. Setiap orang dituntut untuk bersikap yang baik, dan pantas dalam hubungannya dengan orang lain sehingga tercipta kerukunan hidup bersama. Sikap yang buruk terhadap orang lain akan memancing munculnya crah atau konflik. Kondisi ideal ini menekankan sikap dan perilaku yang menjaga kerukunan tersebut, sehingga muncul ungkapan lainnya yang mendorong terwujudnya kerukunan, dan dalam kajian konflik relevan dengan istilah resolusi konflik.

\section{Guyub Rukun sebagai Pandangan Sosial Masyarakat Balun}

Kehidupan bermasyarakat di wilayah Balun berjalan dengan damai, termasuk di dalamnya hubungan antarumat Islam dan umat Katolik saling berrelasi dengan rukun. Kerukunan di Desa Balun terbangun dari budaya lokal, yang berbasis pada budaya Jawa yang sangat menekankan sikap guyub rukun dalam kehidupan bersama. Berbagai ungkapan tradisional yang berisi pesan-pesan moral untuk memelihara hubungan baik dan menghindari konflik dengan orang lain.

Ungkapan-ungkapan tersebut menjadi nilai-nilai dan acuan moral dalam menjalani relasi sosial, sehingga interaksi dengan orang lain berjalan dengan penuh kedamaian. Demikian pula dalam berbagai tradisi yang dijalankan oleh masyarakat, merupakan tradisi yang lintas agama sehingga membangun ikatan solidaritas antarwarga dan menekan potensi konflik antarumat beragama. Tradisi-tradisi yang dilakukan masyarakat Balun memiliki nilai yang memperkuat kohesi sosial, sekaligus di dalamnya mengandung transformasi 
berupa simbolisasi makna spiritual maupun kerukunan bagi kehidupan masyarakat. Ungkapanungkapan tradisional maupun praktekpraktek tradisi tersebut mengarah pada kehidupan bermasyarakat yang guyub rukun.

Budaya guyub rukun ini selaras dengan orientasi hidup masyarakat Jawa yaitu mencapai hidup yang harmoni, dengan Tuhan, lingkungan, dan diri sendiri. Berbagai aspek kehidupan orang Jawa diwarnai dengan tujuan mencapai keseimbangan diri dan harmoni berupa keselarasan dengan Tuhan, lingkungan alam, lingkungan sosial atau masyarakat, dan dengan dirinya sendiri yakni diri yang lahir dengan diri yang batin. Kerukunan dengan sesame manusia sebagai lingkungan sosial, termasuk kerukunan umat beragama, menjadi bagian tujuan hidupnya yaitu mencapai hidup yang harmoni tersebut.

Keseimbangan

keharmonisan hidup tersebut merupakan kesadaran kosmis yang melingkupi kehidupan seseorang yang sadar sebagai orang Jawa. Yakni kesadaran diri untuk senantiasa menyelaraskan keharmonisan antara jagat alit (mikrokosmos) dengan jagat ageng (makrokosmos). Kesadaran tersebut diungkapkan lewat falsafah sangkan paraning dumadi, kesadaran terhadap asal usul dan tujuan penciptaan. Semua berasal dari dan akan kembali kepada Tuhan Yang Maha Esa. Tuhan menjadi asal, sekaligus berada di dalam, serta menjadi tujuan semua kejadian, sehingga kesatuan dan keselarasan menjadi suatu hal yang penting. Sebagaimana diungkapkan dalam penelitian Niels Mulder1, bahwa keteraturan berarti harmoni dengan tujuan kosmos, dan dalam arti terdalam menjadi kemanunggalan, kesatuan dari segala-galanya, pencipta dengan yang diciptakan, kawula dengan gusti, sangkan paran, di mana prinsip kesatuan ini sebagai Tuhan. Dengan demikian tugas penting manusia adalah menjaga ketertiban yang sesungguhnya menjadi kehendak Tuhan dan fitrah kehidupan ini. Bahkan oleh karena ketertiban sudah menjadi fitrah, maka tugas manusia bukan menciptakan ketertiban melainkan hanya menjaga ketertiban tersebut. Itulah yang diungkapkan melalui sepi ing pamrih rame ing gawe.

Makna sepi ing pamrih rame ing gawe adalah bahwa tindakan manusia harus dibebaskan dari pamrih atau kepentingan pribadi, dan hanya bertindak sebagai tanggungjawab sesuai dengan posisinya dalam masyarakat atau kehidupan ini. Pamrih merupakan 
sumber dari konflik dan pertentangan dalam kehidupan, dan tanggungjawab menjadi penyangga keselarasan kehidupan apabila tidak dilaksanakan akan mengganggu keselarasan dan harmoni kehidupan. Sepi ing pamrih merupakan usaha sadar untuk melawan hawa nafsu dalam rangka usaha mencapai ketenangan hati dan kebijaksanaan, melalui pengekangan diri sehingga menimbulkan sikap penuh kebaikan terhadap orang lain bahkan terhadap umat manusia seluruhnya. ${ }^{14}$

Dengan kesadaran atau kawruh sangkan paraning dumadi yang diwujudkan dalam bentuk sepi ing pamrih rame ing gawe, maka interaksi dan berelasi dengan liyan atau orang lain menjadi harmoni. Oleh karena itu dalam konsep konsep aku pribadhi bagi orang Jawa bukanlah suatu keberdiri-sendirian yang menjadi pusat otonomi dan tanggungjawab, tetapi aku orang Jawa adalah dwi-tunggal bahkan tri-tunggal (untuk menyebut jamak) yang berarti adalah aku dan orang lain yang dekat yang sudah diakui dan diakukan. Liyan adalah siapa saja yang berada di luar keakuan tersebut. ${ }^{15}$

${ }^{14}$ Niels Mulder, Kebatinan dan Hidup Sehari-hari Orang Jawa, Kelangsungan dan Perubahan Kulbalunl, (Jakarta: Gramedia, 1980), h. 39.

15 Franz Magnis Suseno dan Reksosusilo, Etika Jawa dalam Tantangan (Sebuah Bunga
Pribadhi dan liyan menjadi keaku-an hanya jika pribadi-pribadi dapat bersikap rukun. Sikap rukun inilah yang menjamin terwujudnya keselarasan dan harmoni. Sikap rukun berarti sikap perdamaian, kerukunan, keselarasan, dan harmoni tanpa pertentangan dan konflik dalam kehidupan. Sikap rukun harus ditunjukkan dalam hubungannya dengan pribadi yang lain yang telah diakui dan diakukan melalui sikap guyub, yakni mau mengenal, bersedia bersama, dan beraktivitas bersama, sebagai satu kesatuan yang selaras dan harmoni sebagai menjadi keselarasan dengan sangkan paraning dumadi. Pada akhirnya, manusia dapat melaksanakan tanggungjawab kehidupan yang hayu atau indah, sebagai kehendak sangkan paraning dumadi. Hal ini diungkapkan dengan memayu hayuning bawana, memperindah-indahkan keindahan semesta.

Manusia tanpa berpretensi membuat keindahan karena sesungguhnya keindahan sudah adikodrati dalam asal dan tujuan penciptaan kehidupan ini. Manusia hanya dituntut untuk sepi ing pamrih rame ing gawe, melalui guyub rukun dalam upaya memayu hayuning bawana. Diungkapkan

Rampai), (Yogyakarta: Penerbit Kanisius, 1983), h. 141-142. 
Suseno ${ }^{16}$ bahwa setiap orang dalam sikap individualnya hendaknya melakukan apa yang dituntut oleh kewajiban pangkatnya -sepi ing pamrih rame ing gawe, hal mana dengan sendirinya berarti telah menyesuaikan diri dengan masyarakat (rukun) dan mengakui tatanan (hormat). Dengan cara ini maka manusia memberi sumbangan paling optimal terhadap keselarasan dalam masyarakat dan kesejahteraan umum, serta akan mencapai ketenangan batin bagi dirinya melalui kelesarasan dan harmoni tersebut. Dunia atau semesta yang indah, yang terwujud dalam keselarasan dan harmoni akan dapat dicapai dalam kehidupan ini.

\section{KESIMPULAN}

Masyarakat Balun di terpilah berdasarkan agama, adalah umat Islam, Katolik dan Kristen. Namun demikian masyarakat ini telah terkenal masyarakat yang rukun dan damai. Namun tidak dipungkiri, dalam hubungan antarumat beragama, terlebih dalam konteks masyarakat yang heterogen, terjadi dinamika dalam interaksi sosialnya. Meskipun demikian, secara umum lingkungan Balun interaksi sosial yang

16 Franz Magnis Suseno, Etika Jawa, Sebuah Analisa Falsafi tentang Kebijaksanaan Hidup Jawa,

(Jakarta: PT. Gramedia Pustaka Utama, 2003), h. 149. terjalin di dalamnya berjalan dengan baik, terutama karena didukung dengan budaya Jawa yang melingkupi masyarakat Balun.

Situasi yang rukun dan damai dalam lingkungan masyarakat Balun, diantaranya ditopang dengan adanya budaya Jawa yang menjadi latar belakang budaya masyarakat Balun. Budaya Jawa ini sangat menekankan kehidupan yang harmonis, damai dan rukun dalam bentuk sikap penghormatan, sikap rukun, toleransi, dan sebagainya menjadi acuan moral dan tingkah laku dalam berhubungan antarumat beragama. Nilainilai budaya ini dikristalisasi dalam bentuk ungkapan-ungkapan tradisional.

Kesimpulan dari hasil penelitian adalah, pertama paradigma masyarakat Balun dalam memahami ajaran agamanya (Islam, Hindu, Kristen) adalah paradigma subtantif-inklusif. Dari pemahaman inklusif kemudian terimplikasi pada prilaku sosi-kultur, sosio-religi yang toleren ditengah perbedaan yang ada di masyarakat Balun.

Faktor yang melatarbelakngi bangunan toleransi yang hidup subur di Desa Balun adalah sebagai berikut: pertama, paradigma masyarakat Balun dalam memahami ajaran agamanya yang inklusif dan subtansialistik. Dari 
pemahaman inklusif kemudian terimplikasi pada prilaku sosi-kultur, sosio-religi yang toleren ditengah perbedaan yang ada di masyarakat Balun. Kedua, kebijakan politik pluralis, sebuah kebijakan politik yang mendistribusikan kekuasaanya (perangkat desa) pada seluruh elemen/kelompok masyarakat yang ada, kekuasaan tidak hanya milik mayoritas (Islam) tetapi dibagi peran dengan minoritas (Kristen dan Hindu) sehingga, akan terbangun sikap saling memiliki untuk membangun desa.

Ketiga, tradisi sosio-kultur toleran yang tumbuh subur di masyarakat. Tradisi sosio-kultur yang toleran sangat mempengaruhi tatanan toleransi beragama yang berbeda di Balun. Keempat, tradisi perkawinan beda agama yang masih terjaga, sehingga memberikan kontribusi terhadap sikap toleransi , karena dari perkawinan beda agama ini akan membutuk ikatan persaudaran dalam ikatan keluarga walaupun beda agama.

Model toleransi yang terpola di Desa Balun adalah sebagai berikut: Pertama, Perangkat desa pluralistik berasal dari seluruh eleman masyarakat yang berbeda agama, Islam, Hindu, Kristen. Kedua, Keluarga Multikultural yang terdiri dari beragam agama (Islam,
Hindu, Kristen) dalam satu atap rumah dalah satu keluaraga. Ketiga, Kenduri/"Ngaturi" Multikultural, adalah kegiatan dalam mensikapi siklus kehidupan (Hamil, Kelahiran, Mendapatkan Rezeqi, Kematian) atau dalam momentum-momentum penting dalam bermasyarakat (HUT RI, Puasa, Hari Raya) dengan menegadakan hajatan yang dipimpin pemuka agama dengan ritual doa dengan sajian makanan dan dapat "berkat" kenduren, dengan mengundang seluruh warga tanpa melihat latar belakang agama. Keempat, Dakwah Inklusif, adalah cara mengajak orang berbuat baik dan memperingatkan orang untuk tidak berbuat jahat dengan cara santun, toleran, menghargai dan menghormati dengan kelompok yang berbeda kultur, agama.

\section{Daftar Pustaka}

Amirrachman, Alpha. 2017. Revitalisasi Kearifan Lokal: Studi Resolusi Konflik di Kalimantan Barat, Maluku dan Poso, Jakarta: ICIP dan European Commission (EC), 2007, www.lsaf.org/content/view/176/ $\underline{150 /}$ diunduh 17 Juni 2017.

Geertz, Hildred. 1985. Keluarga Jawa. Jakarta: Grafiti Press.

Haba, John. 2007. Revitalisasi Kearifan Lokal: Studi Resolusi Konflik di 
Kalimantan Barat, Maluku, dan

Poso. Jakarta: ICIP dan Eropean

Commision.

Khalim, Samidi. 2009. Tradisi Lisan

Masyarakat Jawa. Semarang:

Prima Media Press,.

Marsh, David dan Gerry Stoker. 2002.

Theory and Methods in Politial

Science. Hampshire: Palgrave Macmilla.

Mulder, Niels. 1980. Kebatinan dan Hidup Sehari-hari Orang Jawa, Kelangsungan dan Perubahan Kulbalunl. Jakarta: Gramedia.

Nurhayati, Endang. 2012. "Nilai-Nilai Luhur dalam Ungkapan Jawa sebagai Fondamen Kehidupan Masyarakat Berbudaya", makalah, Konggres Bahasa Jawa ke-5 dikutip dalam http://kidemang.com/kbj5 diunduh 14 September 2017.

Rohimin, et.al,. 2009. Harmonisasi Agama dan Budaya di Indonesia. Jakarta: Balai Litbang Agama Jakarta.

Suseno, Franz Magnis dan Reksosusilo. 1983. Etika Jawa dalam Tantangan (Sebuah Bunga Rampai). Yogyakarta: Penerbit Kanisius.

Suseno, Franz Magnis. 2003. Etika Jawa, Sebuah Analisa Falsafi tentang Kebijaksanaan Hidup Jawa.
Jakarta: PT. Gramedia Pustaka Utama.

Widyastuti, Sri Harti. 2012. "Reaktualisasi Ungkapan Tradisional Jawa Sebagai Sumber Kearifan Lokal dalam Masyarakat untuk Penguat Kepribadian Bangsa", makalah, Konggres Bahasa Jawa ke-5 dikutip dalam http://ki-demang.com/kbj5 , diunduh 14 September 2017. 